\title{
Isolated fourth ventricle
}

眙道膜炎後水頭症に続発した2例

中尾 哲・佐藤 慎一・福光 太郎・尾形 誠宏・黒木 茂一*

\section{Isolated Fourth Ventricle}

\author{
Report of Two Cases
}

Satoshi Nakao, Shinichi Sato, Taro Fukumitsu, Masahiro Ogata and Shigekazu KUROKI*

Departments of Neurosurgery and $*$ Pediatrics, Kobe Central Municipal Hospital, Kobe

\begin{abstract}
Occlusion of the aqueduct of Sylvius and the foramena of Luschka and Magendie results in an abnormal dilatation of the fourth ventricle, because cerebrospinal fluid produced in the fourth ventricle collects excessively within it. This dilated fourth ventricle, i.e., isolated fourth ventricle, is easily diagnosed by computed tomography and is curable by shunting of the ventricle. The isolated fourth ventricle has recently been recognized as a new clinical entity, but its pathophysiology is not fully understood.

In this communication, two cases with isolated fourth ventricle are reported and the relevant literature is reviewed.
\end{abstract}

Key words: isolated fourth ventricle, hydrocephalus, fourth ventricle, aqueductal stenosis, computed tomography

\section{I はじめに}

Isolated fourth ventricle は, 髄液循環路から隔晟された

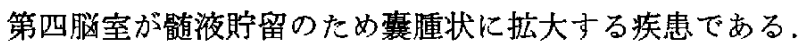
本症は，1975年 DeFeo らにより double compartment hydrocephalus $の$ 名称で 1 例が報告されたのに始まり，CT スキャンの導入により明確な疾患単位として確立されてき たと言える。しかし本邦に扔ける論文報告では数例を散見 するにすぎす5,7,8)，その発生㤌比較的まれと考えられる。

今回我々は，髄膜炎後水頭症の V-P シャント治療後に 発生した本症の 2 例を経験したので，若干の文献的考察を 加え報告する。

\section{II 症例}

<症例 $1>7$ 才，女児（Table 1)

主訴 : 頭痛, 嘔吐
現病歴：生後 2 週時に化膿性髄膜炎のため他院で治療を 受けた。また，生後 2 力半時に水頭症が発生しシャント 手術を，1才 1 月時にはシャント再建術を同様に他院で 受けた。以後，軽度の発育遅延を認める以外に問題はなか ったが，1980年4月10日の夕方から急に強い頭痛を訴光頻 回に嘔吐を繰り返すよらになった。食事も摂取できず元気 もなくなったため, 翌11日本院索受診し入院となった.

入院時所見：意識は清明であるが，元気がなく頭痛を訴 えた，神経学的検查では，運動・知覚麻㾇を認めないが軀 幹失調が著明であり，失調性歩行を示した。また全身理学 的検査で軽度の脱水を認めた，右頭頂部の頭皮下に他院で 受けた V-P シャントの flushing valve が存在したが, 圧 迫に対し抵抗があり機能不全が疑われた。CT スキャンで は後頭蓋窩正中部に楕円形の境界鮮明な low density mass (CT 值 4) が認められ，造影阂投与に和いても増強を受 けず (Fig. 1)，この low density mass は形態とCT 值加

神戸市立中央市民病院脳神経外科 *同小児科

Address reprint requests to: S. Nakao, M. D., Department of Neurosurgery, Kobe Central Municipal Hospital, 4-6 Minatojima-nakamachi, Chuo-ku, Kobe 650.

受稿 1983 年 9 月 19 日 受理 1983 年11月 4 日 
Table 1 Clinical summary of two cases with isolated fourth ventricle

\begin{tabular}{|c|c|c|c|c|c|c|}
\hline \multirow[b]{2}{*}{ Case } & \multirow[b]{2}{*}{$\begin{array}{l}\text { Age, } \\
\text { Sex }\end{array}$} & \multirow[b]{2}{*}{$\begin{array}{l}\text { Prior } \\
\text { diagnosis }\end{array}$} & \multirow[b]{2}{*}{$\begin{array}{l}\text { Interval between } \\
\text { shunting and } \\
\text { diagnosis of } \\
\text { isolated fourth } \\
\text { ventricle }\end{array}$} & \multirow[b]{2}{*}{ Symptoms } & \multirow[b]{2}{*}{ CT findings } & \multirow[b]{2}{*}{ Treatment } \\
\hline & & & & & & \\
\hline 1 & $\begin{array}{l}7 \text { yrs, } \\
\text { female }\end{array}$ & $\begin{array}{l}\text { purulent } \\
\text { meningitis }\end{array}$ & $6 y r s$ & $\begin{array}{l}\text { headache } \\
\text { vomiting } \\
\text { ataxic gait }\end{array}$ & $\begin{array}{l}\text { normal lateral } \\
\text { ventricles and } \\
\text { large fourth } \\
\text { ventricle }\end{array}$ & $\begin{array}{l}\text { revision of lateral } \\
\text { ventricular shunt and } \\
\text { addition of fourth } \\
\text { ventricular shunt with } \\
\text { Y connector }\end{array}$ \\
\hline 2 & $\begin{array}{l}21 \text { months, } \\
\text { female }\end{array}$ & $\begin{array}{l}\text { bacterial } \\
\text { meningitis } \\
\text { (E. coli) }\end{array}$ & 18 months & vomiting & $\begin{array}{l}\text { slit-like lateral } \\
\text { ventricles and } \\
\text { large fourth } \\
\text { ventricle }\end{array}$ & $\begin{array}{l}\text { added fourth venticular } \\
\text { shunt to previous } \\
\text { lateral ventricular } \\
\text { shunt with } Y \text { connector }\end{array}$ \\
\hline
\end{tabular}

ら执張した第四脳室と考えられた。また右側畄室にシャン トチューブがあり，側脳室・第三脳室はほぼ正常の大きさ であった。ついで flushing valve より造影剂を注入しCT ventriculography を施行したところ，側脳室・第三脳室は 良く造影されるが第四脳室以下はまったく造影されず，中

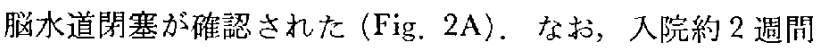
前の症状のない時期に他院で施行された CT スキャンで は，側脳室は slit-like ventricle で第四脳室はすでに抬非 宗していた

以上の所見とシャント造影による腹腔側チューブの閉塞 所見より，側脳室シャントの機能不全と本症と診断した。

手術所見：入院当日，全身麻醉下に V-P シャント再建 術(腹腔側) と第四脳室シャント術を施行した。まず右後頭 蓋窩に穿頭を行い，脳内視鏡 (脳鏡)による観察で CT スキ
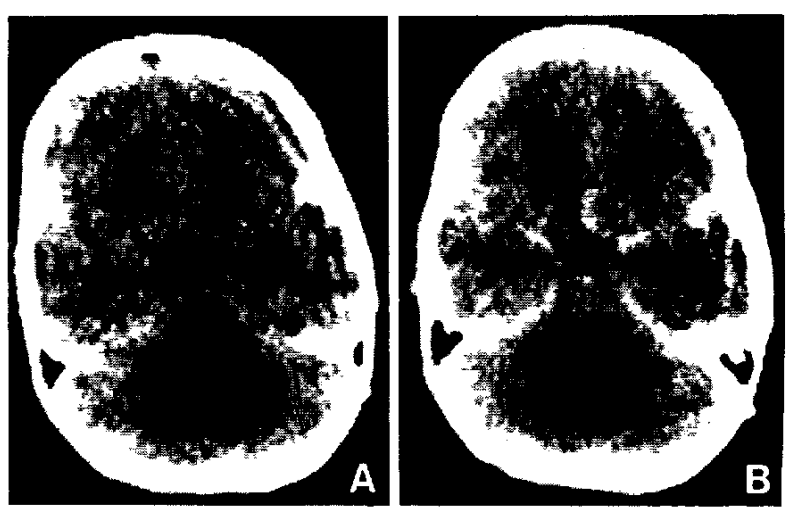

Fig. 1 Case 1. Preoperative computed tomographs (CT) showed a large low density mass in the posterior fossa which was not enhanced after injection of contrast material. The posterior fossa mass was confirmed as the enlarged fourth ventricle by a surgical survey using encephaloscopy. A: Plain CT, B: Contrast enhanced CT.
ヤンの low density mass が腫瘍性病変ではなく第四媨室で あることを確認したのち、シャントチューブを挿入した。

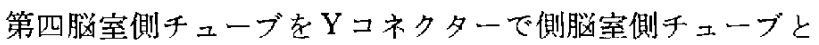
連結し，ついで腹腔側チューブの再建術を行った。術前の 腹腔側チューブの閉塞はチューブの長さが不足し先端が 腹腔内より抜けていたためであることを確諗した。

術後経過: 術直後加頭痛・嘔姓は消失し, 失調性歩行 も軽快・消失した。術後 2 力月目のCTスキャンでは，第 四譄室の桩張は消失し側脳室とともに slit-like となってい た(Fig. 2B).なお，1983年 1 月14日に第四脳室 側チューブの再建術を行っている。

\section{<症例 $2>1$ 才 9 力月，女児 (Table 1)}

主訴：嘔吐

現病歴：生後 2 力月時 (1981年 4 月), 大腸菌性髄膜炎の
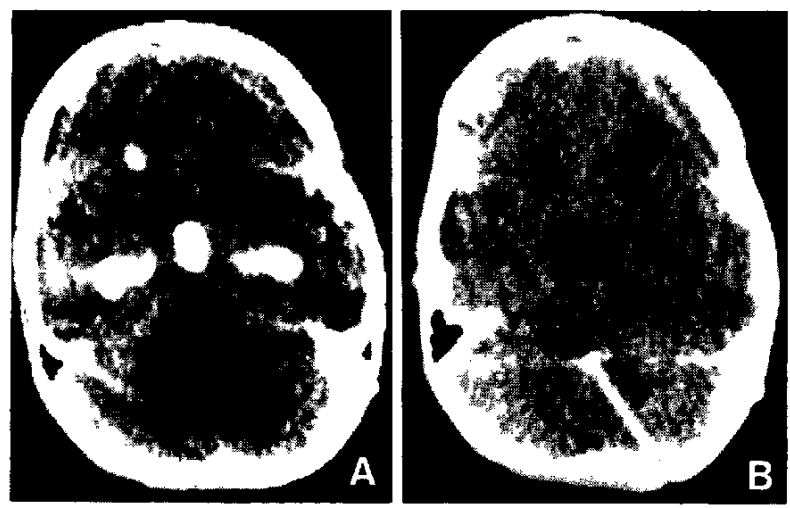

Fig. 2 Case 1. A: CT ventriculography was performed by injecting $2 \mathrm{~m} l$ of $60 \%$ meglumine isotalamate into the lateral ventricle via the lateral ventricular shunt. Because contrast material did not enter into the enlarged fourth ventricle, it was confirmed that the aqueduct of Sylvius was occluded. B: Postoperative CT demonstrated the small fourth ventricle as well as the ventricular catheter. 
ため本院で入院加療を受けた，髄膜炎の経過中に水頭症が

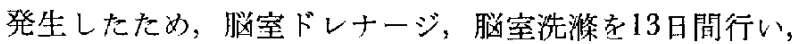
䯣液所見の改善を待って 5 月 7 日に V-P シャントを施行 した。術後 6 日目のCT スキャンですでに slit-like ventricle 示したが, 淽状注改善し約 2 力の臨木経過に て軽快退院した，以後症状もなく精神・運動機能の発達も ほぼ正常であったが，1982年11月26日の朝ミルクを领んだ あと突然嘔叶し元気がなくなったため，本院を受診し入院 となった。

入院時所見：意識は清明であるが元気なく，顔面荅白で あった，神経学的㮩查で注四肢麻痺・失調などの異常所見 は認为なかった。CT スキャンでは両側側脳室は前回同様 に slit-like ventricle であるが，第四脳室の囊腫状应大を 認めた(Fig. 3A)，臨床経過抢上びCT 所見から本症と診 断した。

手術所見：11月27日，全身麻醉下に第四譄室からのシャ ント術を施行した。すず前回の V-P シャント露出して 閉塞がないことを確認し，ついで右後頭蓋窩を穿頭しX線 透視下に第四脳室の穿刺を行った，水様透明な軻液の流出 をみたため脳室側チューブを㧴入し，Yコネクターで側脳 室チェーブと連結し手術を終えた。

術後経過：経過は順調で症状の改善を認め, 約 2 週閒で 退院した. 術後のCT スキャンでは第四脑室の正常化を 認めた(Fig. 3B)。な陉経過中に第四脳室側チューブの閉 塞があり，嘔吐などの頭蓋内圧え進症状に加え失調性歩行 る出現したため，1982年12月22日に再建術を行っている。

\section{III 考 察}

\section{1. 名称}

第四膇室の異常な桩大は，Dandy-Walker 症候群・小腷
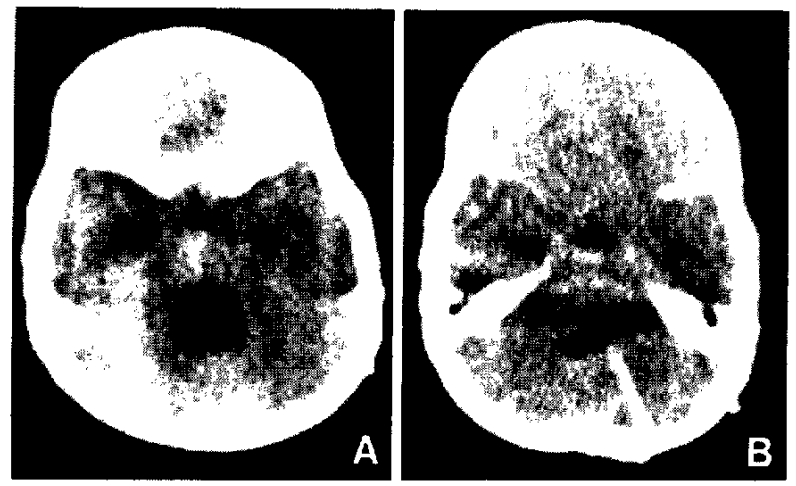

Fig. 3 Case 2. A: Preoperative CT showed the enlarged fourth ventricle with slit-like lateral ventricles. B: CT scan after fourth ventricular shunting disclosed a normal size fourth ventricle.
変性症・脳腫瘍などや交通性水頭症の全脳室系拡大の部分 現象として認められるが，isolated fourth ventricle 子鑑別 すべき特異的な疾患の一っである，本症はCT スキャ ンの導入により容易に診断可能となり注目を集めたこ とから, double compartment hydrocephalus (DeFeo ら, $1975^{1 \prime}$ ), isolated fourth ventricle (Hawkins $5,1978^{4)}$ ), trapped fourth ventricle (Zimmerman $\left.ら ， 1978^{10}\right)$ などの 名称で報告されてきた。本症は後述するごとく，第四脳室 の“弧立”により引き起こされることから Hawkins らの 命名がより理解しやすいと思われたため，本論文では isolated fourth ventricle $の$ 名称を用いた.

\section{2. 病態と発生機序}

本症は, 第四脳寀の流入・流出口である中脳水道やLuschka・Magendie 孔が閉塞し，第四脳室が他の髄液腔から 弧立するため出現する，脳室内で産生される髄液は流出口 が閉塞したため脑室内に貯留し, 結果として第四媨室は囊 腫状に拉大しさ末ざをな症状を呈するようになる，本症に は先行する水頭症があり，V-P シャント術後年単位の期間 を経て発症するのが通常である。

ところで，本症に扔いて第四脳室が弧立に至る機序につ いてはいまだ完全に解明されているとは言いがたく，しか も本症に先行寸る水頭症が必ずしも一定しないことから， その機序は単一ではない上考学られる.Scotti ら”虫，自 験16例につ先行する水頭症交通性水頭症 (communicating hydrocephalus, extraventricular obstructive hydrocephalus), 中脳水道閉塞症 (aqueduct stenosis), Luschka - Magendie 孔閉塞による水頭症 (intraventricular obstructive hydrocephalus due to occlusion of the outlets of the fourth ventricle)の3型に分類し, それぞれの型に掠い て第四脳室が弧立に至る場合を推論している。すなわち， 第四脑室の流入・流出口のどちらか一側がすでに閉塞して いる後 2 者の場合には, シャント術後に炎症や出血が起き 他側が閉塞して第四脳室の弧立に至るとし，また交通性水

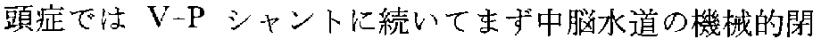
塞があり，ついで感染や出血により第四脳室流出口の閉塞 が起こると考えている。しかし，我々の2例ではV-Pシャ ント術後に出血や感染を疑わせる明らかな病歴を認めず， 中悩水道や Luschka・Magendie 孔が長時間を経て実際ど のよらな機序で閉塞をきたすかは不明である。ただ中脳水 道については水頭症の経過中に二次的汇狭窄や開塞をきた すことが知られて招り, その発生機序として器質的閉塞 (出血や㷋症による閉塞, 执大した中脳水道の縮小による 疫痕化など)ばかりでなく中腷の偏位に伴ら機械的閉塞も

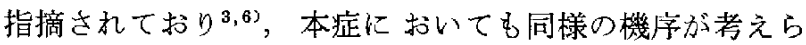
れる，松本らは経過中に中脳水道が一時的に再開通したと 


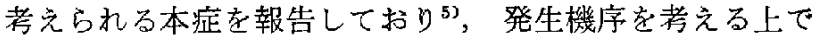
興味深い，また，我々の 2 例孔含め本症の多くが側脑室に ついては slit-like となっていることから，本症をV-P シ ヤントの overfunction 浜よるシャント手術合併症の一つ

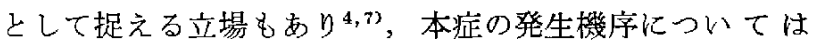
さらに検討を加える必要があろう。

\section{3. 臨床症状}

本症の臨床症状は，脳圧え進症状と運動失調・眼振など の後頭蓋窝症状である。しかし本報告例のごとく後頭蓋窝 症状が前景に立つとはかぎらず，V-P シャントの機能不 全を疑わせ，CT スキャンで初めて診断されることも多い， また無症状の症例子報告されて怙り星，第四脳室の应大と 臨床症状，特に後頭蓋窝症状は必ずしも平行しない上言え

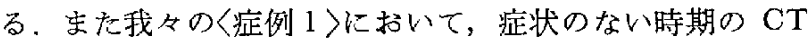
スキャンですでに第四脳室の拡大を認めたことを考えると， 放置されている本症も少なからず存在すると思われる。

\section{4. 診断と鑑別診断}

本症の診断に性 CT スキャンがもっとも有力であり，後 頭蓋窩正中部の low density mass として出現する。この low density mass が 拡大した第四脳室であること，その第 四脳室が㗓液循環路から弧立していることの診断が必要で ある，後頭蓋窩の low density mass として鑑別すべき疾

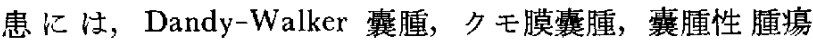
(astrocytoma, hemangioblastoma な $と ゙$ ), large cisterna magna などがあるが，本症が正中部に位置して西洋梨型を 呈し contrast enhancementをまったく受けないことから， その鑑別診断恃比較的容易である。特に水頭症患者に招い て V-P シャント術後に出現した髄液 CT 值に一致した low density mass で注，本症がもっとも疑わしいと言える. また第四脳室の㵦液循環路からの弧立の確定診断には，手 術に上る閉塞の確認がもっとも確かではあるが，〈症例 1〉 のごとく造影剤によるCT ventriculography とその経時的 観察が有用であり，また治療による第四脳室の大きさの経 時的観察でも明らかにしらる。

\section{5. 治療}

治療法，桩大した第四脳室加ら持続的に髄液を排出する ことにるる，髄液徝環路から言えば後頭蓋窝開頭術による 中脳水道の䦥塞除去や第四脳室の開放が理想的であり，好 んで行っている報告者もある ${ }^{2)}$ ，一方第四脳室へのシャン 卜手術の追加はより簡便で合併症む少なく，本報告例のご とく十分な効果が得られることから多くの報告者が採用し て抒り，まず試みるべき手術法と考光られる。ただしここ のような人工的な髄液路が今後新たな合併症を引き起こす 可能性もあり，十分な释過観察が必要と思われる。また， 前述のごとく無症状な本症も報告されているが，これらの
症例に対しても治療が必要か否か怡今後の問題であるう。

\section{$\mathrm{N}$ ま と}

1. 䯣膜炎後水頭症の V-P シャント術後それぞれ 6 年 ・1年 6 力月を経過して isolated fourth ventricle $の$ 発生を みた 7 才と 1 才 9 力月の女览の 2 例を経験した。抬大した 第四脳室の特徴的な CT 所見より診断され，第四脑室か らのシャント手術の迫加により症状の軽快をみた。

2、 Isolated fourth ventricle は，第四脳室が髄波徝環路 から隔離されるため引き起こされるが，本症の発生は比較 的まれであるので文献的考察を加え摯告した。

本論文の要旨の一部は, 第 1 回日本譄神経外科学会近畿地方会 (1981年 3 月，京都)において発表した。

\section{文献}

1) DeFeo D, Foltz EL, Hamilton AE: Double compartment hydrocephalus in a patient with cysticercosis meningitis. Surg Neurol 4: 247-251, 1975

2) Foltz EL, DeFeo DR: Double compartment hydrocephalus -a new clinical entity. Neurosurgery 7: 551-559, 1980

3) Foltz EL, Shurtleff DB: Conversion of communicating hydrocephalus to stenosis or occlusion of the aqueduct during ventricular shunt. $J$ Neurosurg 24: 520-529, 1966

4) Hawkins JC, Hoffman HJ, Humphreys RP: Isolated fourth ventricle as a complication of ventricular shunting. Report of three cases. $J$ Neurosurg 49: 910-913, 1978

5) 松本 悟, 佐藤博美, 增村道雄 : Isolated fourth ventricle. 腷神外科 $9: 897-903,1981$

6) Nugent GR, Al-Mefty $O$, Chou S: Communicating hydrocephalus as a cause of aqueductal stenosis. $J$ Neurosurg $51: 812-818,1979$

7) 大井静雄：小坚水頭症に招ける短絡術後の合併症とし ての slit like ventricle と髓液循環路の隔雕. (Part-1) その 病態と臨床上の諸問題. 小少の譄神 8:107-117,1983

8) 大槻泰介, 吉本高志, 平島 豊 : 脑動静脈奇形手術後に 生した trapped fourth ventricle $の 1$ 例. 慆神外科 9:947 $-950,1981$

9) Scotti G, Musgrave MA, Fitz CR, Harwood-Nash DC: The isolated fourth ventricle in children: CT and clinical review of 16 cases. $A J N R$ 1: 419-424, 1980

10) Zimmerman RA, Bilaniuk LT, Gallo E: Computed tomography of the trapped fourth ventricle. Amer J Roentgen 130: 503-506, 1978

〔別刷請求先： $\mathbf{T} 650$ 兵庫県神戸市中央区港島中町4-6，神戸 市立中央市民病院脳神経外科，中尾 晢] 